\title{
The Empowerment of Women and Children in India
}

\author{
Authors: Gayatri Sunkad \\ Submitted: $\quad$ 23. November 2020 \\ Published: $\quad$ 18. December 2020 \\ Volume: 7 \\ Issue: 6 \\ Affiliation: $\quad$ Shri Kalidas Degree College, The Department of Political Science, \\ Karnataka- Badami, India \\ Languages: English \\ Keywords: Empowerment, Women, Children, economic sector, population, \\ Government, Welfare projects \\ Categories: News and Views, Humanities, Social Sciences and Law \\ DOI: $\quad$ 10.17160/josha.7.6.724
}

\section{Abstract:}

The empowerment in the view of the women in India is necessary because the women population contributes more than $49 \%$ of the nation. A woman is like a captain of the ship and she is having the responsibility in leading the family, balancing the economic condition of the family, and also having the responsibility of educating the children. The empowerment of children is also necessary, in the view of the progress of the nation, because they are the future citizens of the country. The future of the nation depends on the well being of the children. If they are physically and mentally fit, then only they can contribute for the leading of the nation. 


\title{
Empowerment of Women and Children
}

\author{
Smt. Gayatri Sunkad, Shri Kalidas Degree College, \\ The Department of Political Science, Karnataka- Badami, India
}

Keywords: Empowerment, women, children, economic sector, population, Government, Welfare projects etc.

\section{Abstract}

The empowerment in the view of the women in India is necessary because the women population contributes more than $49 \%$ of the nation. A woman is like a captain of the ship and she is having the responsibility in leading the family, balancing the economic condition of the family, and also having the responsibility of educating the children.

The empowerment of children is also necessary, in the view of the progress of the nation, because they are the future citizens of the country. The future of the nation depends on the well being of the children. If they are physically and mentally fit, then only they can contribute for the leading of the nation.

The empowerment of women and children also refers to the social and economic concept which contributes the leading factor in the progress of any nation.

India is basically an agricultural country, and empowerment of women and children automatically takes the highest importance. 
In rural sectors, even though, women are surrounded by blind beliefs, family clashes, sexual harassment even from family members, domestic violence, women still become the captain of the family.

In the urban sector, working men constitute $21 \%$ of the population and compared to other nations, it is comparatively less.

The women are slowly acquiring the dominant position in all fields including education, medical, science, technology, art and including defense forces also. But still she has to lead and struggle in male dominant society, and has to prove her ability.

Nowadays, encouraging the empowerment of women and children, not only applies to the Central as well as State Governmental programmes, even the NGO's are also contributing a considerable share in it.

So many universities also adopted the studies on women and children as a part of curriculum and Karnataka Government had passed the prohibition of child labor and bonded labor act, dowry act, prohibition of child marriage act to stop exploitation of women as well as children.

The Karnataka Government had encouraged to establish "Streeshakti groups" and the state government had established the government schools in all villages to encourage education in the rural sector and also started the scheme such as "Cooliyinda shalege" to stop school dropouts and attract the children towards school.

Introduction: The concept of "Empowerment of Women and Children"' is not a new thing, but it is a basic and important concept of the world. This concept not only applies to India, but it is also seen in all the nations.

Even though India is a predominantly, male dominant nation, still if we are comparing the contribution in all fields is not negligible. Even if we see the women's contribution in rural fields, even the uneducated women contribute to the upliftment of economic condition of the family.

Even the children, also in the rural sector, contribute to the economic condition of the family. Most poor parents send children to work in factories, garages, cinema theaters, etc due to poverty and illiteracy. 
The empowerment of women and children is a strong concept which applies to the leading of the nation and $16 \%$ of the population constitute the children below the age of 16 years and also the people above the age of 60 years. So some time they can be considered as the unproductive sector also.

So converting the unproductive sector to the future productive sector, there is a great necessity of empowerment of women and children.

\section{Objectives:}

1. Analyzing the concept of empowerment of women and children.

2. Preparing the plan about the achievement of the concept of women and children.

3. Identifying problems while applying project into practical shape.

4. Motivating the bureaucracy as well as the common people about the problems faced by women and children.

5. Providing the education to all children including the rural sector.

6. Creating opportunities to all women including rural as well as uneducated women according to their talent.

\section{Methodology:}

By collecting the data figure, and also making surveys, in the rural sector, we could collect information and by using this data, we can make plans about, the encouragement of the improving status of women and children. The methodology is also useful for making future plans, and this data collection can be used in private sector, NGO, in Central and State Government Departments, to make and implement the plans even at administrative level. 
The Economic Survey by Dena Bhattacharya Jan31 2018.

https//www.firstpost.com?India/economicsurvey2017-18-emphasis-on-women empowerment-highlights -need-disaggregats-data-by-genfer-4328959.html

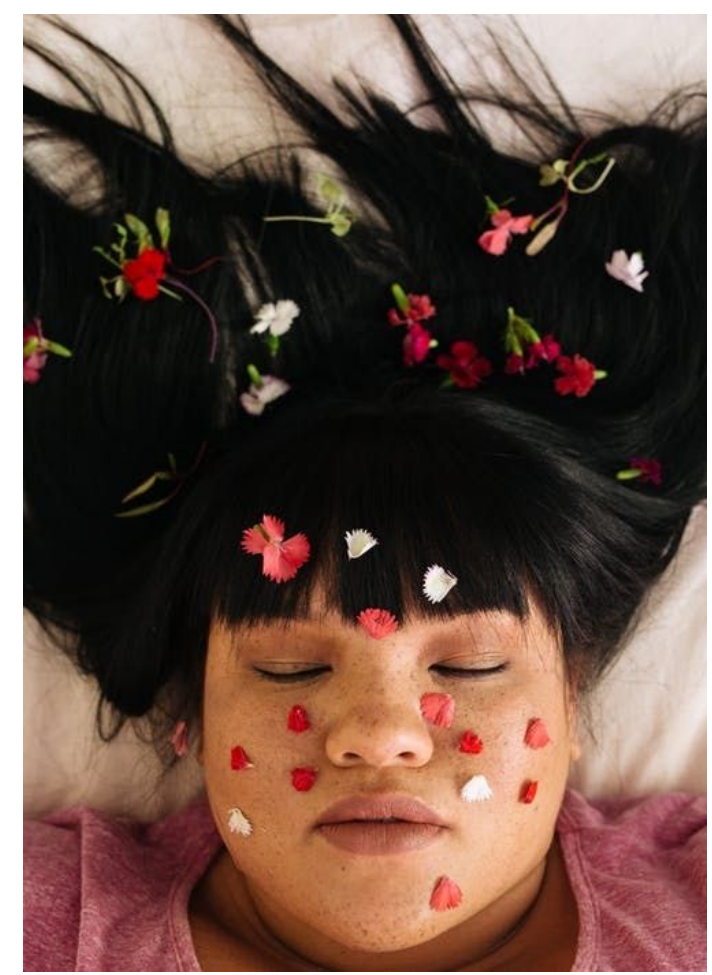

Pink is the color of the Economic Survey 2017-18, signifying the support and promotion of the growing movement to target and end violence against women and to promote women's rights. The chief economic advisor of the finance ministry, Arvind Subramanian stated how the choice of color is a symbol: "In our bid to further the cause of women's empowerment, the cover of Economic Survey 2018 is pink."

The preface of the Survey talks about addressing the deep, ingrained societal issues of gender inequality and how this reflects in the education and reproductive, as well as the economic agency of women in the country. The annual document looked at advancing the gender equality agenda, as it also analyses the progress around gender so far: "Addressing the deep societal meta-preference in favor of sons and empowering women with education and reproductive and economic agency are critical challenges for the Indian economy.

According to the Survey, India's score in 14 out of 17 indicators that relate to the agency, attitude and outcomes have improved over time. In seven of these 
indicators, there has been such consistent progress that India's performance is better than or at par with other countries.

There has been notable progress in the agency dimension for women, who now have an active decision-making power regarding household purchases and visiting family and relatives. There has also been a decline in physical and sexual violence against women, according to the Survey. Moreover, education levels have also improved. The percentage of educated women have gone up from 59.4 percent in 2005-06 to 72.5 percent in 2015-16.

\section{Agency.}

\section{Prepared by Justin Demetriades and based on BRIDGE"s Gender and Indicators Cut Edge Pack 2007}

\section{http://www.bridge.ids.ac.uk/reports gend CEP.htmI\#Indicators}

A 'gender-responsive', 'gender-sensitive', or just 'gender' indicator measures gender-related changes over time. Gender indicators can refer to quantitative indicators based on sex disaggregated statistical data - which provides separate measures for men and women on literacy, for example. Gender indicators can also capture qualitative changes- for example, increases in women's levels of empowerment or in attitude changes about gender equality. Measurements of gender equality might address changes in the relations between men and women, the outcomes of a particular policy, programme or activity for women and men, or changes in the status or situation of men and women, for example levels of poverty or participation

\subsection{Quantitative and Qualitative Approaches Methodology}

\section{Working definition:}

Quantitative methods of data collection produce quantifiable results, so they focus on issues which can be counted, such as percentages of women and men in parliament, male and female wage rates or school enrolment rates for girls and boys. Quantitative data can show changes in gender equality over time - for example, a well used quantitative indicator is the number of girls in school compared to boys. Qualitative Qualitative methodologies capture people's experiences, opinions, attitudes and feelings - for example women's experiences of 
the constraints or advantages of working in the informal sector, or men's and women's views on the causes and consequences of domestic violence. Often participatory methodologies such as focus group discussions and social mapping tools are used to collect data for qualitative indicators. Qualitative data can also be collected through surveys measuring perceptions and opinions. One example is "Program $\mathrm{H}^{\prime}$ which was developed in Latin America to promote more gender-equitable attitudes among young men.

\section{Empowerment of Women in India:}

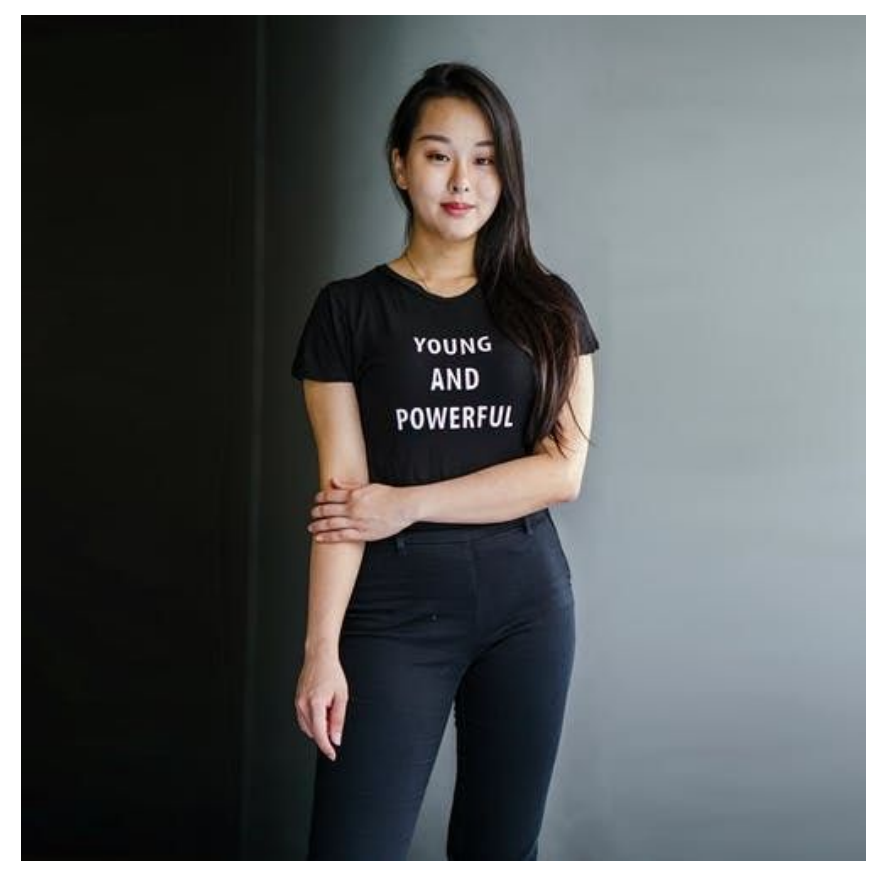

Empowerment of Women in India: A Critical Analysis Dr. B. Nagaraja , M.A. PhD Associate Professor Department of Economics Sri Venkateswara University College of Arts Sri Venkateswara University TIRUPATI

According to Census-2011, India has reached the population of 1210 million, as against 301 million in 1951, of which 58,64,69,174 (48.5\%) were females. The population of India accounted for $17.5 \%$ of the total world population and occupied second place. The sex ratio was 930 in 1971 and it has increased to 940 according to 2011 Census. The female literacy also increased from $18.3 \%$ in 1961 to $74.0 \%$ in 2011 and a decrease in male-female literacy gap from $26.6 \%$ in 1981 to 16.7 per cent in 2011. Women empowerment in India is heavily dependent on many different variables that include geographical location (rural/urban), educational status, social status (caste and class) and age. Policies on women empowerment exist at national, state and local levels in many sectors including health, education, economic 
opportunities, gender based violence and political participation. The scope and coverage of the schemes launched has been expanding that include initiatives for economic and social empowerment of women and for securing gender equality. The following schemes at present are aiming at women empowerment and gender equality in India:

1. Integrated Child Development Services (ICDS) (1975)

2. Rajiv Gandhi Scheme for Empowerment of Adolescent Girls (RGSEAG) (2010)

3. The Rajiv Gandhi National Crèche Scheme for Children of Working Mothers.

4. Integrated Child Protection Scheme (ICPS) (2009-10)

5. Support to Training and Employment Programme for Women (STEP)

6. Dhanalakshmi (2008)

7. Short Stay Homes

8. Swadhar

9. Ujjawala (2007)

10. Scheme for Gender Budgeting (XI Plan)

\section{National Mission for Empowerment of Women}

12. Rashtriya Mahila Kosh (1993)

In spite of the effective implementation of all the above schemes and programmes,, there are significant gaps between policy achievements and actual practice at the community level. The Global Gender Gap Index (2012) observed that India is simply not doing enough for its women. The ranking of the country has fallen from 113 (out of 134 countries) in 2010 to 113 and out of 135 countries in 2011 . However, in 2012, its ranking has improved from 113 in 2011 to 105 with a score of 0.644 in 2012 according to the recent report of the World Economic Forum. The World Report-2012 released by the Human Rights Watch (Events of 2011) also observed that social unrest and protests deepened in resource rich areas of central and eastern India, where rapid economic growth was accompanied by rapidly growing inequality. Despite repeated claims of progress by the Government, there was no significant improvement in access to health care and education. According to the 
latest statistics released by World Economic Forum(2012) indicate that the current situation of gender gaps is alarming and India ranks after our neighbor country Srilanka in all sub-indices except in political empowerment.

Table. 1. Details of Gender Gap Index -2012 (Out of 135 Countries) Gender Gap sub-Indices India Sri Lanka Rank Score Rank Score

\begin{tabular}{|l|c|c|c|c|}
\hline $\begin{array}{l}\text { Gender sub gap } \\
\text { indices }\end{array}$ & $\begin{array}{c}\text { India } \\
\text { Rank }\end{array}$ & $\begin{array}{l}\text { India } \\
\text { Score }\end{array}$ & $\begin{array}{l}\text { Srilanka } \\
\text { Rank }\end{array}$ & $\begin{array}{l}\text { Srilanka } \\
\text { Score }\end{array}$ \\
\hline Economic participation and opportunity & 123 & 0.4588 & 105 & 0.5596 \\
\hline Educational attainment & 121 & 1.8525 & 108 & 0.9946 \\
\hline Health survival & 134 & 0.9612 & 1 & 09796 \\
\hline Political empowerment & 17 & 0.3343 & 22 & 03151 \\
\hline Over all index & 105 & 0.6442 & 39 & 0.7122 \\
\hline
\end{tabular}

\section{Conclusion:}

The empowerment of women and children is having equal importance as well as necessary for the development of any nation. Empowerment means not only providing better opportunities as well as education, it also aims at motivating them to step with the mainstream. It is necessary for a successful democracy. For the 
healthy creation of society, it is necessary to create healthy women and also healthy future citizens.

The half of the population constitutes the women who beget the children which becomes the future focus of any country.

The Central Government, state government and even private NG.Os are trying their best to achieve this motto. Let us hope in this direction.

Source: World Economic Forum (2012) Global Gender gap Index -2012, p.10-11. The rankings and scores for India amply proves that it is found in the lower rank even compared to Sri Lanka in all sub-indexes of gender equality. India gained eight places

\section{References:}

planningcommission.nic.in/plans/planrel/fiveyr/9th/vol2/v2c3-8.htm

\section{EMPOWERMENT OF WOMEN AND DEVELOPMENT OF CHILDREN.}

wcd.nic.in/women development/national-policy-women-empowerment

www.wcd.nic.in/about-us/vision-and-mission

\section{National Mission for Empowerment of Women-Ministry of Women}

\section{Gender equality: empowered women raise healthier children | Global ...}

https://www.theguardian.com/global.../sep/.../nutrition-gender-women-empowerme nt

planningcommission.nic.in/plans/planrel/fiveyr/9th/vol2/v2c3-8.htm

planningcommission.nic.in/plans/mta/mta-9702/mta-ch13.pdf

https://en.wikipedia.org/wiki/Women\%27s_empowerment

https://www.worldvision.org/gender-equality.../seven-ways-empower-women-girls

\section{7 ways to empower women and girls | World Vision}

https://www.worldvision.org/gender-equality.../seven-ways-empower-women-girls 
Journal of Science, Humanities and Arts

National Policy for Women Empowerment | Ministry of Women \& Child wcd.nic.in women development/national-policy-women-empowerment

Vision and Mission | Ministry of Women \& Child Development

www.wcd.nic.in/about-us/vision-and-mission

How Women's Empowerment Shapes Children's Schooling, Nutrition ...

a4nh.cgiar.org/.../how-women's-empowerment-shapes-children's-schooling-nutritio $\mathrm{n} /$

THE END 
Journal of Science, Humanities and Arts

\section{About the Author:}

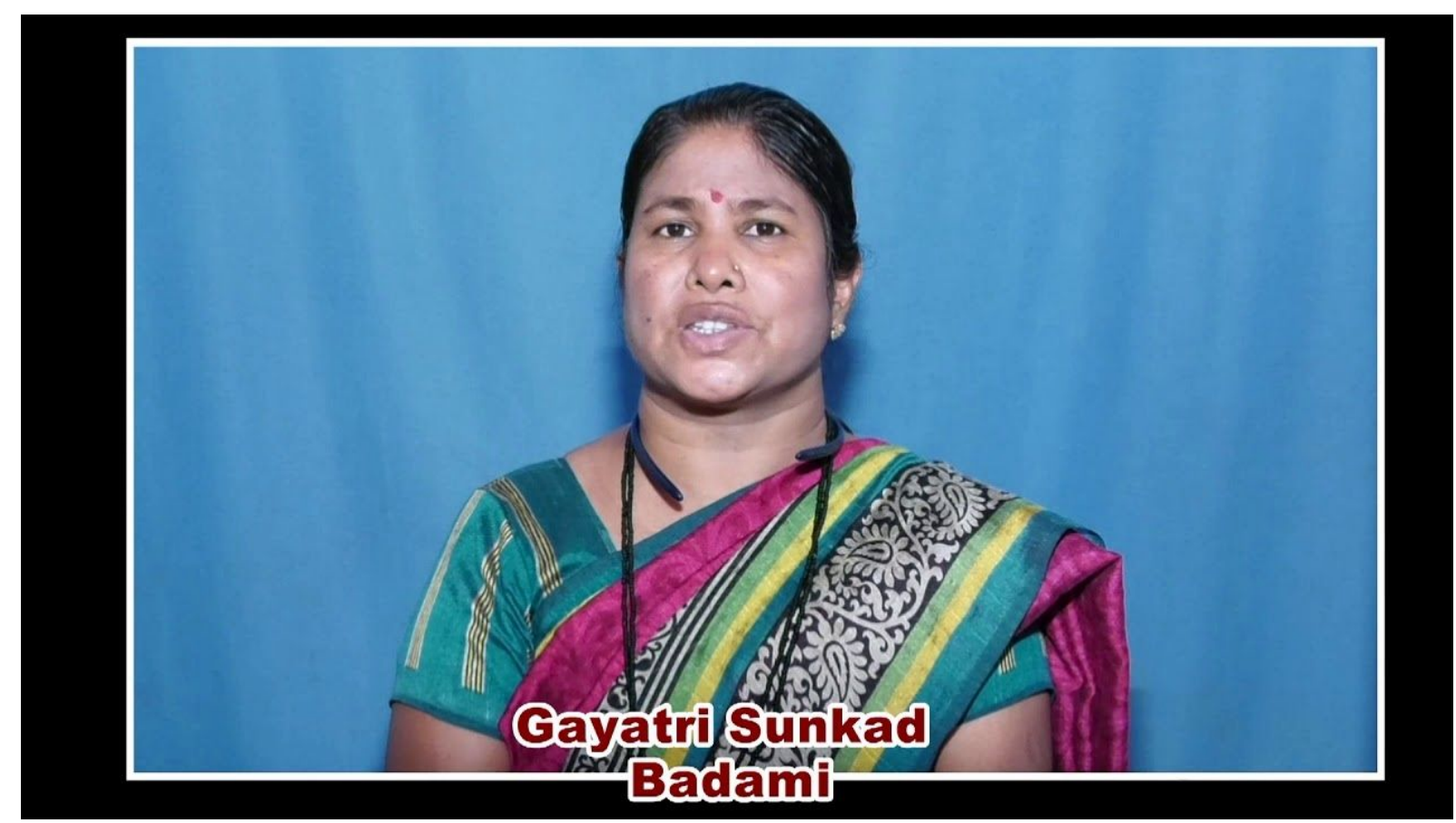

Published articles- Women Entrepreneurs- the Issues and Challenges- volume1 Issue 2 October-December 2015

Mahila Pratishtha - International Multidisciplinary Journal on Women and Gender Studies

The Role of women in agriculture- Rani Channamma University Belagavi 2016 ISBN; 978-81-928928-4-9

The importance of education in the empowerment of women- 2016- Krantiveer Sangolli Rayanna College of Education

Worked as a lecturer in Kalidas Degree College Badami fro more than 10 years

Member of ResearchGate and life time member of the social science and humanities research association

The Articles" The Election System in India ", The Role of Globalization", The "Social Problems in India and their solution", The public finance and Budget "are published by international journal and in open access.

"The Education System in India" was published by notion press Tamil Nadu was launched by Amazon and flip kart 